\title{
Diet, serum homocysteine levels and ischaemic heart disease in a Mediterranean population
}

\author{
George E. Vrentzos ${ }^{1}$, John A. Papadakis ${ }^{1}$, Niki Malliaraki ${ }^{2}$, Evagelos A. Zacharis ${ }^{3}$, \\ Elias Mazokopakis ${ }^{1}$, Andreas Margioris ${ }^{2}$, Emmanuel S. Ganotakis ${ }^{1 \star}$ and Anthony Kafatos ${ }^{4}$ \\ Departments of ${ }^{1}$ Internal Medicine \\ ${ }^{2}$ Clinical Chemistry and \\ ${ }^{3}$ Cardiology, University Hospital of Crete, PO Box 1352, Heraklion 71110, Crete, Greece \\ ${ }^{4}$ Social Medicine, Preventive Medicine and Nutrition Clinic, University Hospital of Crete, Heraklion, Crete, Greece
}

(Received 10 October 2003 - Revised 24 December 2003 - Accepted 17 February 2004)

\begin{abstract}
Homocysteine (Hcy) is recognised as a risk factor for IHD. Serum Hcy is negatively correlated with serum folate levels, the main sources of which are fruits, vegetables and legumes. The present case-control study was designed to examine the relationship between serum Hcy levels and IHD and to assess the role of dietary factors in the southern Mediterranean population of Crete, Greece. Serum Hcy, folate, vitamin $\mathrm{B}_{12}$, creatinine and glucose levels and a full lipid profile were measured in 152 patients with established IHD, median age 64 (range 33-77) years, and 152 healthy control subjects, age- and sex-matched. Dietary data were assessed using a $3 \mathrm{~d}$ food intake record. Compared with controls, patients with IHD had significantly higher daily intakes of vitamin $\mathrm{B}_{12}$ and MUFA and significantly lower intakes of carbohydrate, fibre, folate, cholesterol, $n-3$ fatty acids and total trans unsaturated fatty acids. Moreover, patients had significantly higher serum Hcy, vitamin $\mathrm{B}_{12}$ and creatinine levels, but significantly lower folate. Serum folate concentrations in both groups had a significant positive correlation with dietary fibre consumption and a significant inverse correlation with vitamin $\mathrm{B}_{12}$ intake. IHD patients should be encouraged to increase their daily dietary intake of fibre, folate and $n-3$ fatty acids, which are significant components of the traditional Cretan Mediterranean diet. Where dietary folate intake is inadequate, folate supplements are recommended to reduce elevated Hcy levels.
\end{abstract}

Homocysteine: Cretan Mediterranean diet: Folate: Ischaemic heart disease

Elevated plasma homocysteine (Hcy) levels are recognised as a conditional risk factor for atherothrombotic vascular disease in coronary, peripheral, and cerebrovascular arterial circulation (Grundy et al. 1999; Weiss et al. 2002). Hcy is an intermediary amino acid formed by the conversion of dietary methionine to cysteine (Nguyen \& McLaughlin, 2002) and is catabolised either by remethylation to methionine or by trans-sulfuration to cystathionine (Haynes, 2002). Remethylation can occur either by methionine synthase (folate and vitamin $\mathrm{B}_{12}$ dependent), or by betaine-homocystaine methyltransferase; the methyl donor being 5-methyl-tetrahydrofolate (a derivative of folic acid), and betaine, respectively. Trans-sulfuration is catalysed by cystathionine $\beta$-synthase and requires the cofactor vitamin $\mathrm{B}_{6}$ (Cook et al. 2002; Haynes, 2002).

The atherogenic mechanism of Hcy-induced vascular damage is still not clearly understood. It is assumed that Hcy is toxic to the vascular wall, causing endothelial dysfunction (Woo et al. 1997). Elevated Hcy levels may stimulate the proliferation of vascular smooth muscle cells and impair endothelial function (Welch \& Loscalzo,
1998). The interaction of Hcy and endothelial cells may also be followed by platelet activation and thrombus formation (Thambyrajah \& Townend, 2000).

Dietary and environmental factors may modify serum Hcy concentrations. Among the factors known to influence Hcy metabolism are several nutrients, including folate, vitamin $B_{12}$ and vitamin $B_{6}$ (Stein \& McBride, 1998). Nutritional deficiencies of these cofactors are associated with hyperhomocysteinaemia (Welch \& Loscalzo, 1998; Eikelboom et al. 1999). An inverse relation has been shown between serum Hcy levels and the dietary intake of folate and vitamin $\mathrm{B}_{12}$ (Selhub et al. 1993; Rimm et al. 1998).

The traditional Cretan Mediterranean diet has been shown to reduce the risk of cardiovascular events (Kafatos et al. 1991; Trichopoulou et al. 2003) and has been popularised as a healthy diet (Renaud et al. 1995). In particular, the consumption of fruits and vegetables appears to have a protective effect against IHD (Brouwer et al. 1999a; Joshipura et al. 2001). Cross-sectional analyses from the Framingham Heart Study indicate that the frequent consumption of 
certain foods (fruits, vegetables, and cereals) correlates with low plasma levels of Hcy, perhaps as a result of the high folate content of these foods (Tucker et al. 1996). Dietary intervention studies, using diets high in fresh fruit and vegetables, have also reported a decrease in plasma Hcy concentration (Broekmans et al. 2000; Silaste et al. 2003).

Principal components of the Cretan diet are olive oil, fruits, vegetables, legumes, fish, and wine (Kafatos et al. 1997). The benefits of this diet go beyond its antioxidant properties, since high intakes of plant foods rich in folate, vitamins $B_{12}$ and $B_{6}$ may consequently reduce serum Hcy levels (Appel et al. 2000). Recent data suggest that a $5 \mu \mathrm{mol} / \mathrm{l}$ reduction in Hcy should lower vascular disease risk by one-third (Boushey et al. 1995).

The aim of the present study was to investigate the association between dietary intake (particularly dietary folate intake), nutritional status, serum Hcy levels and IHD in the southern Mediterranean population of Crete, Greece.

\section{Methods}

\section{Subjects}

We enrolled 152 patients (136 men and sixteen women) with IHD who were admitted to our hospital over the last 2 years. Patients were considered to have IHD if they had at least one of the following: (1) previous myocardial infarction; (2) history of non-Q infarction or unstable angina; (3) positive stress electrocardiogram and/or echocardiogram.

We excluded patients who had a recent myocardial infarction ( $\leq 6$ weeks) (Egerton et al. 1996) or renal dysfunction (serum creatinine $>15 \mathrm{mg} / \mathrm{l} ; 133 \mu \mathrm{mol} / \mathrm{l}$ ). Patients with clinical evidence of malignant disease and/or receiving vitamin supplements or other medications that could interfere with Hcy levels were also excluded.

Major coronary risk factors for each patient, such as age, sex, hypertension, diabetes mellitus, dyslipidaemia, cigarette smoking, and obesity, were recorded.

The control group consisted of 152 healthy subjects (126 men and twenty-six women) matched for age and sex to patients, with no symptoms of IHD, no other concomitant disease, and who did not take vitamin supplements or medication interfering with Hcy levels.

All subjects were residents of rural areas in one county (Heraklion) of the island of Crete, recruited following public invitation by primary care physicians of seven health centres throughout the county.

\section{Dietary intake}

Dietary intake was evaluated by the $3 \mathrm{~d}$ weighed food record. Patients and subjects were given detailed oral and written instructions regarding the completion of a $3 \mathrm{~d}$ weighed food record consisting of two mid-week and one weekend day. This method is considered to be one of the most practical dietary assessment methods used (Schroder et al. 2001).

Dietary intakes were assessed using a food composition database program developed in the Department of Social
Medicine (Preventive Medicine and Nutrition Clinic) of the University of Crete, which includes analyses contributed by Wageningen Agricultural University, the TNO Nutrition and Food Research Institute, The Netherlands (Transfair Programme), and uses the US Department of Agriculture database version 11.1 adjusted for Greek foods.

Patients and controls provided written informed consent according to the Helsinki declaration.

\section{Definitions}

Diabetics were considered as those who had a fasting serum glucose level $>1260 \mathrm{mg} / \mathrm{l}(7.0 \mathrm{mmol} / \mathrm{l})$, or who were treated with oral antidiabetic agents or insulin.

As all our patients had established IHD, those with serum levels of LDL-cholesterol (LDL-C) $>1300 \mathrm{mg} / \mathrm{l}$ $(3.4 \mathrm{mmol} / \mathrm{l})$ and/or triacylglycerols (TG) $>1500 \mathrm{mg} / \mathrm{l}$ $(1.7 \mathrm{mmol} / \mathrm{l})$ were classified as having dyslipidaemia.

Normal Hcy concentrations range from 6 to $12 \mu \mathrm{mol} / 1$ in the fasting state. Hyperhomocysteinaemia was defined as levels greater than $12 \mu \mathrm{mol} / 1$ (Welch \& Loscalzo, 1998; Friedman et al. 2001).

\section{Clinical and laboratory investigations}

All samples were collected the morning after $10 \mathrm{~h}$ of overnight fasting with water only allowed. Serum levels of Hcy, folate and vitamin $B_{12}$ were measured using an $I_{X}$ Analyzer (Abbott Labs, Abbott Park, IL, USA). Serum concentrations of total cholesterol, HDL-cholesterol (HDL-C), and TG were measured using an automated chemistry analyser (Olympus AU-600; Olympus Diagnostics Systems, Eastleigh, Hants, UK) with reagents from the same manufacturer. LDL-C was calculated according to the Friedewald formula except for samples with serum TG above $4000 \mathrm{mg} / \mathrm{l}(4.5 \mathrm{mmol} / \mathrm{l})$, for which LDL-C could not be determined with the method used. Serum apo A1, apo B100, and lipoprotein (a) were measured by immune nephelometry (lipoprotein (a) test, apo A1 test and apo B100 test; Beckman Instruments Inc., Galway, Republic of Ireland). Renal function profiles and serum glucose concentration were determined by standard methods in routine use.

The department of Clinical Chemistry of Crete University Hospital participates in several quality-assurance programmes and has full clinical pathology accreditation.

\section{Statistical analysis and presentation of results}

Values are expressed as medians and ranges. All $P$ values are two-tailed. Between-group results were assessed by Mann-Whitney tests. Frequency analysis was by the $\chi^{2}$ test, with Yate's correction. Correlation was assessed by Spearman's correlation $\left(r_{\mathrm{s}}\right)$.

\section{Results}

\section{Patient characteristics}

The characteristics of the 152 patients with IHD and the 152 controls enrolled in the present survey are listed in 
Table 1. Hypertension and diabetes were present in eightynine $(58.6 \%)$ and fifty $(32.9 \%)$ patients, respectively. Twenty patients $(13.2 \%)$ were on statin therapy.

Daily intake of dietary components in patients with ischaemic heart disease and controls

Patients had significantly higher daily vitamin $B_{12}$ and MUFA intake, and significantly lower carbohydrate, fibre, folate, cholesterol, $n-3$ fatty acids and total trans unsaturated fatty acids intake (Table 2). Additionally, IHD patients had significantly lower daily energy intake compared with controls (Table 2).

Serum homocysteine, folate, vitamin $B_{12}$ and creatinine levels of ischaemic heart disease patients and controls

Serum Hcy, vitamin $B_{12}$ and creatinine levels were significantly higher and folate was significantly lower in patients (Table 3). Furthermore, there was no significant difference in serum Hcy levels between patients receiving or not receiving statins $(16.0 v .13 .7 \mu \mathrm{mol} / \mathrm{l})$.

Table 1. Patients' and controls' demographics (Medians and ranges)

\begin{tabular}{|c|c|c|c|c|}
\hline & \multicolumn{2}{|c|}{ Controls (n 152) } & \multicolumn{2}{|c|}{$\begin{array}{l}\text { Patients with IHD } \\
\qquad(n 152)\end{array}$} \\
\hline & Median & Range & Median & Range \\
\hline Age (years) & 63 & $40-77$ & 64 & $33-7$ \\
\hline Men: $n$ & \multirow{2}{*}{\multicolumn{2}{|c|}{$\begin{array}{l}126 \\
82.9\end{array}$}} & \multicolumn{2}{|c|}{136} \\
\hline$\%$ & & & \multicolumn{2}{|c|}{89.5} \\
\hline $\begin{array}{l}\text { Smokers: } n \\
\%\end{array}$ & \multicolumn{2}{|c|}{43} & \multicolumn{2}{|c|}{$\begin{array}{l}70 \\
46 \cdot 1^{\star \star}\end{array}$} \\
\hline BMI $\left(\mathrm{kg} / \mathrm{m}^{2}\right)$ & $27 \cdot 1$ & $15 \cdot 6-41 \cdot 1$ & 27.9 & $18 \cdot 1-36.0$ \\
\hline
\end{tabular}

\section{Lipids profile of ischaemic heart disease patients and controls}

Patients had significantly lower serum total cholesterol, LDL-C and HDL-C concentrations, while their TG levels were higher (Table 3). In IHD patients, statin administration did not affect lipid levels significantly (data not shown).

Moreover, they had significantly higher lipoprotein (a) and lower apo A1 and apo B100 serum levels (Table 3).

\section{Correlation of serum total homocysteine, folate and} vitamin $B_{12}$ levels with dietary components

Serum folate concentration significantly correlated with daily fibre consumption $\left(r_{\mathrm{s}} 0.137 ; P=0.019\right)$ and inversely with $24 \mathrm{~h}$ vitamin $\mathrm{B}_{12}$ intake $\left(r_{\mathrm{s}}-0.142 ; P=0.015\right)$.

There was no significant correlation either between serum Hcy, folate and vitamin $\mathrm{B}_{12}$ levels and the daily consumption of other dietary products, or between serum and dietary folate and vitamin $\mathrm{B}_{12}$ levels.

\section{Linear regression analysis}

Among twenty potential risk factors for IHD (Tables 2 and 3) proceeding to a linear regression analysis, only low serum apo A1, and HDL-C levels, and high serum creatinine concentrations, as well as low daily fibre consumption were independently and significantly associated with the presence of IHD.

\section{Discussion}

The present study showed that patients with IHD had significantly higher serum Hcy levels compared with controls. This is in agreement with the literature where subjects with elevated Hcy concentration are not only at high risk for

Table 2. Daily uptake of dietary components in patients and controlst

(Medians and ranges)

\begin{tabular}{|c|c|c|c|c|}
\hline & \multicolumn{2}{|c|}{ Controls (n 152) } & \multicolumn{2}{|c|}{ Patients with IHD (n 152) } \\
\hline & Median & Range & Median & Range \\
\hline Protein (g) & $69 \cdot 4$ & $18 \cdot 0-210 \cdot 4$ & $66 \cdot 0$ & $21 \cdot 1-140 \cdot 5$ \\
\hline Total fat (g) & 103.5 & $49 \cdot 1-220 \cdot 9$ & 105.5 & $33 \cdot 2-183 \cdot 3$ \\
\hline Carbohydrate (g) & $160 \cdot 2$ & $43 \cdot 4-444 \cdot 8$ & $113 \cdot 9^{\star \star \star}$ & $21 \cdot 1-291 \cdot 7$ \\
\hline Fibre $(\mathrm{g})$ & $19 \cdot 1$ & $4 \cdot 7-54.4$ & $15 \cdot 1^{\star \star \star}$ & $1 \cdot 3-38 \cdot 7$ \\
\hline Energy (kJ) & 8176 & $3527-15803$ & $7130^{\star \star \star}$ & $2770-15803$ \\
\hline Vitamin E (mg) & 11.5 & $1 \cdot 3-19 \cdot 3$ & $11 \cdot 2$ & $2.6-23.9$ \\
\hline Vitamin C (mg) & $75 \cdot 3$ & $1 \cdot 0-360 \cdot 4$ & $72 \cdot 5$ & $2 \cdot 2-334 \cdot 3$ \\
\hline Vitamin $B_{6}(\mathrm{mg})$ & $1 \cdot 2$ & $0 \cdot 2-2 \cdot 6$ & $1 \cdot 2$ & $0.3-2 \cdot 4$ \\
\hline Vitamin $B_{12}(\mu \mathrm{g})$ & $2 \cdot 2$ & $0.1-18 \cdot 7$ & $2 \cdot 6^{*}$ & $0.2-53.7$ \\
\hline Folate $(\mu \mathrm{g})$ & 254 & $68-1105$ & $180^{\star \star \star}$ & $34-574$ \\
\hline Cholesterol (mg) & 224 & $35-965$ & $189^{\star}$ & $22-694$ \\
\hline SFA (g) & $24 \cdot 3$ & $9 \cdot 9-93 \cdot 1$ & $24 \cdot 0$ & $8.9-56.9$ \\
\hline MUFA (g) & 55.5 & $17 \cdot 9-96 \cdot 1$ & $60 \cdot 3^{\star \star}$ & $14 \cdot 4-100 \cdot 3$ \\
\hline PUFA (g) & $10 \cdot 5$ & $4 \cdot 01-31 \cdot 4$ & $10 \cdot 4$ & $3 \cdot 4-30 \cdot 5$ \\
\hline Total trans unsaturated fatty acids (g) & $1 \cdot 1$ & $0.02-7.6$ & $0 \cdot 8^{\star \star}$ & $0.04-3.4$ \\
\hline$n-6$ fatty acids $(\mathrm{g})$ & $9 \cdot 0$ & $2 \cdot 8-27 \cdot 6$ & $8 \cdot 9$ & $2 \cdot 0-28 \cdot 3$ \\
\hline$n-3$ fatty acids (g) & 0.7 & $0 \cdot 34-4 \cdot 8$ & $0.6^{\star \star}$ & $0.2-1.8$ \\
\hline
\end{tabular}

SFA, saturated fatty acids.

Median value was significantly different from that for the control group: ${ }^{\star} P<0.05,{ }^{* \star} P<0.01,{ }^{\star \star \star} P<0.001$.

†For details of subjects and procedures, see Table 1 and p. 1014. 
Table 3. Serum levels of homocysteine (Hcy), folate, vitamin $B_{12}$, creatinine and lipid values of ischaemic heart disease patients and controls† (Medians and ranges)

\begin{tabular}{|c|c|c|c|c|}
\hline & \multicolumn{2}{|c|}{ Controls ( $n$ 152) } & \multicolumn{2}{|c|}{ Patients with IHD ( $n$ 152) } \\
\hline & Median & Range & Median & Range \\
\hline Hcy $(\mu \mathrm{mol} / \mathrm{l})$ & $12 \cdot 5$ & $6 \cdot 6-44 \cdot 7$ & $13 \cdot 9^{\star \star}$ & $6 \cdot 6-50 \cdot 0$ \\
\hline Folate $(\mathrm{ng} / \mathrm{ml})$ & 7.9 & $2 \cdot 4-15 \cdot 5$ & $6 \cdot 9^{\star \star}$ & $2 \cdot 5-20 \cdot 0$ \\
\hline Vitamin $\mathrm{B}_{12}(\mathrm{pg} / \mathrm{ml}) \ddagger$ & 326 & $91-835$ & $374^{\star *}$ & $82->2000$ \\
\hline Creatinine $(\mathrm{mg} / \mathrm{l}) \S$ & 8 & $6-14$ & $9^{\star \star \star}$ & $6-21$ \\
\hline Total cholesterol $(\mathrm{mg} / \mathrm{l}) \|$ & 2300 & $1520-3240$ & $2070^{\star \star \star}$ & $1190-3420$ \\
\hline Triacylglycerols $(\mathrm{mg} / \mathrm{l})$ q & 1240 & $400-3810$ & $1450^{\star}$ & $410-5810$ \\
\hline HDL-cholesterol (mg/l) \| & 500 & $300-930$ & $370^{\star \star \star *}$ & $170-730$ \\
\hline LDL-cholesterol (mg/l)\|\| & 1540 & $840-2270$ & $1350^{\star \star \star}$ & $520-2610$ \\
\hline Lipoprotein (a) (mg/l) & 120 & $20-1180$ & $240^{\star \star *}$ & $31-1180$ \\
\hline Apo A1 (mg/l) & 1360 & $890-2130$ & $1030^{\star \star *}$ & $750-1450$ \\
\hline Apo B100 (mg/l) & 1170 & $610-1780$ & $1040^{\star \star}$ & $450-1600$ \\
\hline
\end{tabular}

Median value was significantly different from that for the control group: ${ }^{\star} P<0.05,{ }^{\star \star} P \leq 0.01$, ${ }_{* \star *} P<0.001$.

†For details of subjects and procedures, see Table 1 and p. 1014

$\ddagger$ Serum levels of vitamin $B_{12}$ greater than $2000 \mathrm{pg} / \mathrm{ml}$ (our cut-off limit) are represented here as $>2000 \mathrm{pg} / \mathrm{ml}$.

$\S$ To convert $\mathrm{mg} / \mathrm{l}$ to $\mathrm{mmol} / \mathrm{l}$, multiply by 8.84 .

$\|$ To convert $\mathrm{mg} / \mathrm{l}$ to $\mathrm{mmol} / \mathrm{l}$, multiply by 0.0026 .

9 To convert $\mathrm{mg} / \mathrm{l}$ to $\mathrm{mmol} / \mathrm{l}$, multiply by 0.00113 .

IHD (Stampfer et al. 1992; Wald et al. 1998; Bots et al. 1999; Whincup et al. 1999), but also have more extensive coronary atherosclerosis (Vrentzos et al. 2004).

Patients with IHD had significantly lower serum folate concentrations and an inverse correlation between serum Hcy and folate levels was shown. Hcy concentrations depend on a series of intracellular metabolic reactions in which folate acts as a substrate (Das, 2003) and even subclinical deficiency of this vitamin can increase serum Hcy levels (Haynes, 2002). There was no significant correlation between serum folate levels and the daily dietary intake of folate. Dietary sources of folate in our population covered a wide range of food products apart from fruit and vegetables. Thus the lack of a statistically significant correlation between dietary intake and serum folate levels could possibly be explained by variations in the bioavailability of folate in different foods (Brouwer et al. 1999a), and/or by the paucity of accurate chemical analyses of micronutrients in determining dietary intake for some Greek recipes. However, the fact that IHD patients had both significantly lower serum folate concentration, and daily dietary folate intake compared with controls, indicates a relationship between intake and serum concentration. In addition, others found a strong correlation between total folate intake and serum folate levels (Jacques et al. 1993; Selhub et al. 1993).

The higher serum Hcy levels of our IHD patients could be partly explained by the slight increase of serum creatinine levels. The kidneys play a significant role in Hcy clearance and metabolism since they contain appreciable levels of both trans-sulfuration and remethylation enzymes (Friedman et al. 2001). Serum creatinine is a marker of glomerular filtration rate as well as of future cardiovascular events (Mann et al. 2003). Glomerular filtration rate values estimated from serum creatinine are inversely correlated with plasma Hcy levels (Ducloux et al. 2000).
The daily vitamin $\mathrm{B}_{12}$ intake of IHD patients was higher than that of controls. Man is unable to synthesise vitamin $\mathrm{B}_{12}$, which is derived from animal products, particularly meat. Vitamin $\mathrm{B}_{12}$ may have a beneficial effect on fasting levels of Hcy (Appel et al. 2000), but in our patients serum vitamin $B_{12}$ levels were not associated with Hcy levels.

The present data suggest that dietary folate intake had a major influence on fasting Hcy levels, whereas vitamin $\mathrm{B}_{12}$ had no effect. Interestingly, the majority of our population ( $84.2 \%$ of controls and $97.4 \%$ of patients) had a daily folate intake lower than European recommendations ( $>400 \mu \mathrm{g} / \mathrm{d}$ ) (de Bree et al. 1997; Hassapidou \& Fotiadou, 2001; Kafatos \& Codrington, 2001).

IHD patients had a significantly lower dietary fibre intake than controls. Increased dietary fibre intake, from fruits, vegetables, legumes, and cereals, has been associated with a lower risk for IHD (Rimm et al. 1996; Liu et al. 2002). In the present study, daily fibre consumption significantly correlated with serum folate concentration, as both these components share the same food sources.

Patients and case subjects also had a significantly lower $n$-3 fatty acids intake. Epidemiological studies and controlled clinical trials have demonstrated beneficial effects of $n-3$ fatty acids on CHD (AHA Scientific Statement, 2001; $\mathrm{Hu} \&$ Willet, 2003). Moreover, Bucher et al. (2002) in a meta-analysis suggest that $n-3$ fatty acids intake reduces overall mortality, mortality due to myocardial infarction, and sudden death in patients with IHD. An increased intake of $n-3$ fatty acids from fish, fish oil supplements, or plant sources should be considered essential for IHD patients (Carroll \& Roth, 2002).

IHD patients had lower serum total cholesterol, LDL-C, HDL-C, apo B100 and apo A1 and higher TG and lipoprotein (a) serum levels when compared with controls. In a previous study (Papakonstantinou et al. 2002), we showed that low HDL-C levels are the principal lipid 
abnormality in patients with acute myocardial infarction in the southeast part of Greece. This pattern (low HDL-C and elevated TG) seems to be the lipid pattern of IHD patients in this area. In addition, HDL-C, apo A, and lipoprotein (a) are not directly diet dependent (Katan et al. 1995). Finally, the incidence of smoking was higher among IHD patients than controls $(46.1$ v. $28.3 \%)$. The harmful effects of smoking on HDL-C and TG levels are well known (Mikhailidis et al. 1998).

The prevalence of cardiovascular disease has increased during the last 30 years in Crete (Voukiklaris et al. 1996), a trend that appears to be related to dietary and lifestyle changes that have been taking place (Kafatos et al. 2000). Notable among these have been dramatic reductions in physical activity and also the gradual abandonment of the traditional Cretan diet. The Cretans now have higher saturated fat $(+25 \%)$ and lower monounsaturated fat $(-20 \%)$ intakes, indicating increases in the consumption of meat and cheese, and simultaneously decreases in the mean daily consumption of bread, fruits, vegetables, potatoes, and fibre (Kafatos et al. 1997). Decreases in vegetable and fruit consumption, both good sources of folate, will reduce folate status and increase Hcy concentrations (Tucker et al. 1996).

A recent trial of individuals with established IHD showed that a Mediterranean diet rich in fruits and vegetables and $\alpha$-linolenic acid substantially reduced the recurrence of IHD events for up to 4 years compared with a regular low-fat diet (relative risk 0.28; CI $0 \cdot 15$, 0.53). However, the Mediterranean diet did not alter, at least qualitatively, the usual relationships between major risk factors and recurrence (de Lorgeril et al. 1999).

In IHD patients, serum Hcy levels are a significant predictor of late cardiac events (Stubbs et al. 2000) and increased mortality risk, possibly as a consequence of atherosclerotic changes (Knekt et al. 2001), independently of other traditional risk factors (Nygard et al. 1997). Wald et al. (2002) showed that lowering Hcy concentrations by $3 \mu \mathrm{mol} / \mathrm{l}$ (achievable by increasing folic acid intake) would reduce the risk of IHD by $16 \%$ (11 to $20 \%$ ), deep-vein thrombosis by $25 \%$ (8 to $38 \%$ ), and stroke by $24 \%$ (15 to $33 \%)$. In our patients it is essential to reduce the high Hcy levels (Vrentzos et al. 2000). This could be achieved by increasing the consumption of folate, not only from foods rich in folate (de Lorgeril et al. 1994; Singh et al. 2002), but also with low doses of folate supplements (Brouwer et al. 1999b; Jacques et al. 1999; Riddell et al. 2000; Rampersaud et al. 2003). Adequate dietary folate intake may be recommended for individuals with Hcy $>10 \mu \mathrm{mol} / \mathrm{l}$ (de Bree et al. 1997; Malinow et al. 1999). Treatment with folic acid has been shown to reduce serum Hcy concentration and significantly improve endothelial dysfunction in patients with IHD (Title et al. 2000; Verhaar et al. 2002; Willems et al. 2002), but the effect on cardiovascular morbidity and mortality is as yet unknown (Voutilainen et al. 2001).

To conclude, the present data suggest that IHD patients should be encouraged to increase their daily dietary intakes of fibre, folate and $n-3$ fatty acids, which are significant components of the traditional Cretan Mediterranean diet.
Where dietary folate intake is inadequate, folate supplements are recommended to reduce elevated Hcy.

\section{Acknowledgements}

We thank the team of Preventive Medicine and Nutrition Clinic at the University of Crete, Frosso Bervanaki, Ioanna Apostolaki, Sofia Flouri and Caroline Codrington for their valuable assistance in the present study.

\section{References}

AHA Scientific Statement (2001) Summary of the scientific conference on dietary fatty acids and cardiovascular health. J Nutr 131, 1322-1326.

Appel LJ, Miller ER III, Jee SH, Stolzenberg-Solomon R, Lin PH, Erlinger T, Nadeau MR \& Selhub J (2000) Effect of dietary patterns on serum homocysteine: results of a randomized, controlled feeding study. Circulation 102, 852-857.

Bots ML, Launer LJ, Lindemans J, Hoes AW, Hofman A, Witteman JC, Koudstaal PJ \& Grobbee DE (1999) Homocysteine and short-term risk of myocardial infarction and stroke in the elderly: the Rotterdam Study. Arch Intern Med 159, 38-44.

Boushey CJ, Beresford SA, Omenn GS \& Motulsky AG (1995) A quantitative assessment of plasma homocysteine as a risk factor for vascular disease. Probable benefits of increasing folic acid intakes. JAMA 247, 1049-1057.

Broekmans WM, Klopping-Ketelaars IA, Schuurman CR, Verhagen $\mathrm{H}$, van den Berg H, Kok FJ \& van Poppel G (2000) Fruits and vegetables increase plasma carotenoids and vitamins and decrease homocysteine in humans. J Nutr 130, $1578-1583$.

Brouwer IA, van Dusseldorp M, West CE, Meyboom S, Thomas CM, Duran M, van het Hof KH, Eskes TK, Hautvast JG \& Steegers-Theunissen RP (1999a) Dietary folate from vegetables and citrus fruit decreases plasma homocysteine concentrations in humans in a dietary controlled trial. J Nutr 129, 1135-1139.

Brouwer IA, van Dusseldorp M, Thomas CM, Duran M, Hautvast JG, Eskes TK \& Steegers-Theunissen RP (1999b) Low-dose folic acid supplementation decreases plasma homocysteine concentrations: a randomized trial. Am J Clin Nutr 69, 99-104.

Bucher HC, Hengstler P, Scindler C \& Meier G (2002) N-3 polyunsaturated fatty acids in coronary heart disease: a meta-analysis of randomized controlled trials. Am J Med 112, 298-303.

Carroll D \& Roth M (2002) Evidence for the cardioprotective effects of omega-3 fatty acids. Ann Pharmacother 36 , 1950-1956.

Cook JW, Taylor LM, Orloff SL, Landry GJ, Moneta GL \& Porter JM (2002) Homocystein and arterial disease experimental mechanisms. Vasc Pharmacol 38, 293-300.

Das UN (2003) Folic acid says NO to vascular disease. Nutrition 19, 686-692.

de Bree A, van Dusseldorp M, Brouwer IA, van het Hof KH \& Steegers-Theunissen RP (1997) Folate intake in Europe: recommended, actual and desired intake. Eur J Clin Nutr 51, 643-660.

de Lorgeril M, Renaud S, Mamelle N, Salen P, Martin JL, Monjaud I, Guidollet J, Touboul P \& Delaye J (1994) Mediterranean alpha-linolenic acid-rich diet in secondary prevention of coronary heart disease. Lancet 343, 1454-1459.

de Lorgeril M, Salen P, Martin JL, Monjaud I, Delaye J \& Mamelle N (1999) Mediterranean diet, traditional risk factors, and the rate of cardiovascular complications after myocardial 
infarction: final report of the Lyon Diet Heart Study. Circulation 99, 779-785.

Ducloux D, Motte G, Challier B, Gibey R \& Chalopin JM (2000) Serum total homocysteine and cardiovascular disease occurrence in chronic, stable renal transplant recipients: a prospective study. Am J Soc Nephrol 11, 134-137.

Egerton W, Silberberg J, Crooks R, Ray C, Xie L \& Dudman N (1996) Serial measures of plasma homocyst(e)ine after acute myocardial infarction. Am J Cardiol 77, 759-761.

Eikelboom JW, Lonn E, Genest J Jr, Hankey G \& Yusuf S (1999) Homocyst(e)ine and cardiovascular disease: a critical review of the epidemiologic evidence. Ann Intern Med 131, 363-375.

Friedman AN, Bostom AG, Selhub J, Levey AS \& Rosenberg IH (2001) The kidney and homocysteine metabolism. J Am Soc Nephrol 12, 2181-2189.

Grundy SM, Pasternak R, Greenland P, Smith S Jr \& Fuster V (1999) Assessment of cardiovascular risk by use of multiplerisk-factor assessment equations: a statement for healthcare professionals from the American Heart Association and the American College of Cardiology. Circulation 100, 1481-1492.

Hassapidou M \& Fotiadou E (2001) Dietary intakes and food habits of adolescents in northern Greece. Int J Food Sci Nutr 52, 109-116.

Haynes WG (2002) Hyperhomocysteinemia, vascular function and atherosclerosis: effects of vitamins. Cardiovasc Drugs Therapy 16, 391-399.

Hu F \& Willet W (2003) Optimal diets for prevention of coronary heart disease. JAMA 288, 2569-2578.

Jacques PF, Selhub J, Bostom AG, Wilson PW \& Rosenberg IH (1999) The effect of folic acid fortification on plasma folate and total homocysteine concentrations. $N$ Engl J Med 40, $1449-1454$.

Jacques PF, Sulsky SI, Sadowski JA, Phillips JC, Rush D \& Willett WC (1993) Comparison of micronutrient intake measured by a dietary questionnaire and biochemical indicators of micronutrient status. Am J Clin Nutr 57, 182-189.

Joshipura KJ, Hu FB, Manson JE, et al. (2001) The effect of fruit and vegetable intake on risk for coronary heart disease. Ann Intern Med 134, 1106-1114.

Kafatos A \& Codrington C (editors) (2001) The Eurodiet reports and proceedings. Nutrition and diet for healthy lifestyles in Europe: science and policy implications. Public Health Nutr 4, 265-273.

Kafatos A, Diacatou A, Voukiklaris G, Nikolakakis N, Vlachonikolis J, Kounali D, Mamalakis G \& Dontas AS (1997) Heart disease risk-factor status and dietary changes in the Cretan population over the past $30 \mathrm{y}$ : the Seven Countries Study. Am J Clin Nutr 65, 1882-1886.

Kafatos A, Kouroumalis I, Vlachonikolis I, Theodorou C \& Labadarios (1991) Coronary-heart-disease risk-factor status of the Cretan urban population in the 1980s. Am J Clin Nutr 54, 591-598.

Kafatos A, Verhagen H, Moschandreas J, Apostolaki I \& Van Westerop J (2000) Mediterranean diet of Crete: foods and nutrient content. J Am Diet Assoc 100, 1487-1493.

Katan MB, Zock PL \& Mensink RP (1995) Dietary oils, serum lipoproteins, and coronary heart disease. Am J Clin Nutr 61, 1368S-1373S.

Knekt P, Reunanen A, Alfthan G, Heliovaara M, Rissanen H, Marniemi J \& Aromaa A (2001) Hyperhomocystinemia. A risk factor or a consequence of coronary heart disease? Arch Intern Med 161, 1589-1594.

Liu S, Buring JE, Sesso HD, Rimm EB, Willett WC \& Manson JE (2002) A prospective study of dietary fiber intake and risk of cardiovascular disease among women. J Am Coll Cardiol 39, 49-56.

Malinow R, Bostom A \& Krauss R (1999) Homocyst(e)ine, diet, and cardiovascular diseases. A statement for healthcare professionals from the nutrition committee, American Heart Association. Circulation 99, 178-182.

Mann JFE, Dulau-Forea I \& Franke J (2003) Looking for people at high cardiovascular risk? Look at serum-creatine. Eur Heart J 24, 381-383.

Mikhailidis DP, Papadakis JA \& Ganotakis ES (1998) Smoking, diabetes and hyperlipidaemia. $J R$ Soc Health 118, 91-93.

Nguyen VHD \& McLaughlin MA (2002) Coronary artery disease in women: a review of emerging cardiovascular risk factors. Mountsinai J Med 69, 338-349.

Nygard O, Nordrehaug JE, Refsum H, Ueland PM, Farstad M \& Vollset SE (1997) Plasma homocysteine levels and mortality in patients with coronary artery disease. N Engl J Med 337, 230-236.

Papakonstantinou D, Alexopoulos E, Vrentzos G, Papadakis JA \& Ganotakis E (2002) Serum lipid abnormalities in patients with acute myocardial infarction. Atherosclerosis 3, Suppl. 2, 112.

Rampersaud GC, Kauwell GP \& Bailey LB (2003) Folate: a key to optimizing health and reducing disease risk in the elderly. $J$ Am Coll Nutr 22, 1-8.

Renaud S, de Lorgeril M, Delaye J, Guidollet J, Jacquard F, Mamelle N, Martin JL, Monjaud I, Salen P \& Toubol P (1995) Cretan Mediterranean diet for prevention of coronary heart disease. Am J Clin Nutr 61, Suppl. 6, 1360S-1367S.

Riddell LJ, Chisholm A, Williams S \& Mann JI (2000) Dietary strategies for lowering homocysteine concentrations. Am J Clin Nutr 71, 1448-1454.

Rimm EB, Ascherio A, Giovannucci E, Spiegelman D, Stampfer MJ \& Willett WC (1996) Vegetable, fruit, and cereal fiber intake and risk of coronary heart disease among men. JAMA 275, 447-451.

Rimm EB, Willett WC, Hu FB, Sampson L, Colditz GA, Manson JE, Hennekens C \& Stampfer MJ (1998) Folate and vitamin B6 from diet and supplements in relation to risk of coronary heart disease among women. JAMA 279, 359-364.

Schroder H, Covas MI, Marrugat J, Vila J, Pena A, Alcantara M \& Masia R (2001) Use of a three-day estimated food record, a 72-hour recall and a food-frequency questionnaire for dietary assessment in a Mediterranean Spanish population. Clin Nutr 20, 429-437.

Selhub J, Jacques PF, Wilson PW, Rush D \& Rosenberg IH (1993) Vitamin status and intake as primary determinants of homocysteinemia in an elderly population. JAMA 270, 2693-2698.

Silaste ML, Rantala M, Alfthan G, Aro A \& Kesaniemi YA (2003) Plasma homocysteine concentration is decreased by dietary intervention. Br J Nutr 89, 295-301.

Singh R, Dubnov G, Niaz M, Ghosh S, Singh R, Rastogi SS, Manor O, Pella D \& Berry EM (2002) Effect of an IndoMediterranean diet on progression of coronary artery disease in high risk patients (Indo-Mediterranean Diet Heart Study): a randomized single-blind trial. Lancet 360, 1455-1461.

Stampfer MJ, Malinow MR, Willett WC, Newcomer LM, Upson B, Ullmann D, Tishler PV \& Hennekens CH (1992) A prospective study of plasma homocyst(e)ine and risk of myocardial infarction in US physicians. JAMA 268, 877-881.

Stein JH \& McBride PE (1998) Hyperhomocysteinemia and atherosclerotic vascular disease. Arch Intern Med 58, $1301-1306$.

Stubbs PJ, Al-Obaidi MK, Conroy RM, Collinson PO, Graham IM \& Noble MI (2000) Effect of plasma homocysteine concentration on early and late events in patients with acute coronary syndromes. Circulation 102, 605-610.

Thambyrajah J \& Townend JN (2000) Homocysteine and atherothrombosis - mechanisms for injury. Eur Heart $J$ 21, 967-974. 
Title LM, Cummings PM, Giddens K, Genest JJ Jr \& Nassar BA (2000) Effect of folic acid and antioxidant vitamins on endothelial dysfunction in patients with coronary artery disease. J Am Coll Cardiol 36, 758-765.

Trichopoulou A, Costacou T, Bamia C \& Trichopoulos D (2003) Adherence to a Mediterranean diet and survival in a Greek population. $N$ Engl J Med 348, 2599-2608.

Tucker KL, Selhub J, Wilson PW \& Rosenberg IH (1996) Dietary intake pattern relates to plasma folate and homocysteine concentrations in the Framingham Heart Study. $J$ Nutr 126, 3025-3031.

Verhaar MC, Stroes E \& Rabelink TJ (2002) Folates and cardiovascular disease. Arterioscler Thromb Vasc Biol 22, 6-13.

Voukiklaris GE, Kafatos A \& Dontas AS (1996) Changing prevalence of coronary heart disease risk factors and cardiovascular diseases in men of a rural area of Crete from 1960 to 1991. Angiology 47, 43-49.

Voutilainen S, Rissanen TH, Virtanen J, Lakka TA \& Salonen JT (2001) Low dietary folate intake is associated with an excess incidence of acute coronary events: the Kuopio Ischemic Heart Disease Risk Factor Study. Circulation 103, 2674-2680.

Vrentzos G, Ganotakis E, Zacharis E, Delaveraki E, Vardakis K, Papadakis J, Gravanis A \& Emmanouel D (2000) Hyperhomocysteinemia in patients with ischaemic heart disease and Mediterranean dietary pattern. Atherosclerosis 151, Suppl. 1, 104.

Vrentzos G, Papadakis JA, Malliaraki N, Zacharis EA, Katsogridakis K, Margioris A, Vardas PE \& Ganotakis ES (2004)
Association of serum total homocysteine with the extent of ischaemic heart disease in a Mediterranean cohort. Angiology 55 (In the Press).

Wald DS, Law M \& Morris J (2002) Homocysteine and cardiovascular disease: evidence on causality from a meta-analysis. BMJ 325, 1202-1206.

Wald NJ, Watt HC, Law MR, Weir DG, McPartlin J \& Scott JM (1998) Homocysteine and ischemic heart disease: results of a prospective study with implications regarding prevention. Arch Intern Med 158, 862-866.

Weiss N, Keller C, Hoffmann U \& Loscalzo J (2002) Endothelial dysfunction and atherothrombosis in mild hyperhomocysteinemia. Vasc Med 7, 227-239.

Welch G \& Loscalzo J (1998) Homocysteine and atherothrombosis. N Engl J Med 338, 1042-1050.

Whincup PH, Refsum H, Perry IJ, Morris R, Walker M, Lennon L, Thomson A, Ueland PM \& Ebrahim SB (1999) Serum total homocysteine and coronary heart disease: prospective study in middle aged men. Heart 82, 448-454.

Willems F, Aengevaeren W, Boers G, Blom HJ \& Verheugt FW (2002) Coronary endothelial function in hyperhomocysteinemia: improvement after treatment with folic acid and cobalamin in patients with coronary artery disease. $J$ Am Coll Cardiol 40, 766-772.

Woo KS, Chook P, Lolin YI, Cheung AS, Chan LT, Sun YY, Sanderson JE, Metreweli C \& Celermajer DS (1997) Hyperhomocyst(e)inemia is a risk factor for arterial endothelial dysfunction in humans. Circulation 96, $2542-2544$. 